\title{
First report of leaf spot of Phlox paniculata caused by Septoria phlogis in Korea
}

\author{
Ji-Hyun Park • Mi-Jeong Park • Sun-Hee Hong • \\ Hyeon-Dong Shin
}

Received: 15 March 2012 / Accepted: 14 May 2012 / Published online: 1 June 2012

(C) Australasian Plant Pathology Society Inc. 2012

\begin{abstract}
Leaf spot was observed on garden phlox (Phlox paniculata) in Yesan, Korea, in 2008. Based on the morphological characteristics of the fungus and the host genus, the isolate was identified as Septoria phlogis. Internal transcribed spacer sequences of rDNA of the isolate confirmed its close affinity to previously known species of Septoria. In 2010 and 2011, the disease was observed in Hoengseong, Korea. This is the first report of Septoria leaf spot on garden phlox in Korea.
\end{abstract}

Keywords Garden phlox · Leaf spot · Phlox paniculata . Septoria phlogis

Phlox paniculata L., commonly called garden phlox, is a perennial plant with large blossom heads, which is valued for its pleasing summer garden color and fragrance. The plant is native to the eastern United States and was introduced to Korea at the beginning of the 20th century. Several horticultural varieties are widely planted for ornamental purposes in Korea. Various fungal diseases of the garden phlox have been reported in North America and Europe (Farr and Rossman, 2012). However, no fungal diseases other than powdery mildew (Park et al. 2010) have been reported in Korea.

In August 2008, a previously unknown disease with small necrotic lesions on leaves of the garden phlox was

J.-H. Park $\cdot$ M.-J. Park $\cdot$ H.-D. Shin $(\bowtie)$

Division of Environmental Science and Ecological Engineering,

Korea University,

Seoul 136-701, South Korea

e-mail: hdshin@korea.ac.kr

S.-H. Hong

Institute of Environment and Ecology, Korea University,

Seoul 136-701, South Korea found in a hobby garden in Yesan, central Korea. Initial symptoms were circular to irregular, purplish-brown spots that expanded to form distinct lesions usually not exceeding $5 \mathrm{~mm}$ in diameter. The lesions tended to become grayishwhite with a purplish to blackish-brown border line (Fig. 1a-b). Dark brown conidiomata formed on the lesions (Fig. 1c). In a humid environment, which could be mimicked by placing the diseased leaves in a humid chamber overnight, white to cream-coloured conidial cirrhi were produced from the conidiomata (Fig. 1d).

For identification of the causal agent, leaf lesions with mature conidiomata were detached from the diseased fresh leaves using a scalpel and water-mounted on glass slides. Each structure was examined in bright field and differential interference contrast light microscopy. At least 20 measurements were made for each structure. The mycological description was based on a representative sample (KUSF23612, Korea, Yesan, August 2008, leg. H.D. Shin).

Conidiomata were pycnidial, epigenous, rarely hypogenous, scattered, dark-brown to rusty-brown, globose, immersed in host tissue or somewhat erumpent, $60-120 \mu \mathrm{m}$ in diameter, with an ostiole of $20-40 \mu \mathrm{m}$ in diameter (Fig. 1e). Conidia were filiform, rarely acicular, sub-straight to mildly curved, more-or-less truncate at the base, obtuse at the apex, hyaline, eguttulate, $25-75(-95) \times 1.5-2.2 \mu \mathrm{m}$, and 1-4(-5)septate (Fig. 1f). Based on the morphological characteristics of the fungus and the host genus, the isolate was consistent with Septoria phlogis Sacc. \& Speg. as shown in Table 1 (Saccardo 1878; Jørstad, 1965; Bai et al. 2003; Priest 2006). The same symptoms and signs of the disease were observed on garden phlox in 2010 and 2011 in Hoengseong, Korea. Voucher specimens $(n=5)$ were housed in the Korea University herbarium (KUS).

Single spore isolates (Fig. 1g) were successfully obtained on potato dextrose agar (PDA) and an isolate was deposited 
Fig. 1 Leaf spots on the leaves of Phlox paniculata infected with Septoria phlogis. a Symptoms of young leaves. b A leaf showing typical lesions with purplish- to blackishbrown border line. c Close-up view of lesions dotted with dark brown conidiomata. d Conidia cirrhi protruding from conidiomata immersed in host tissue. e A conidioma producing conidia through an ostiole. Scale bar= $50 \mu \mathrm{m}$. f Conidia. Scale bar $=20$ $\mu \mathrm{m}$. g Seven-week-old colonies of $S$. phlogis growing on a potato dextrose agar
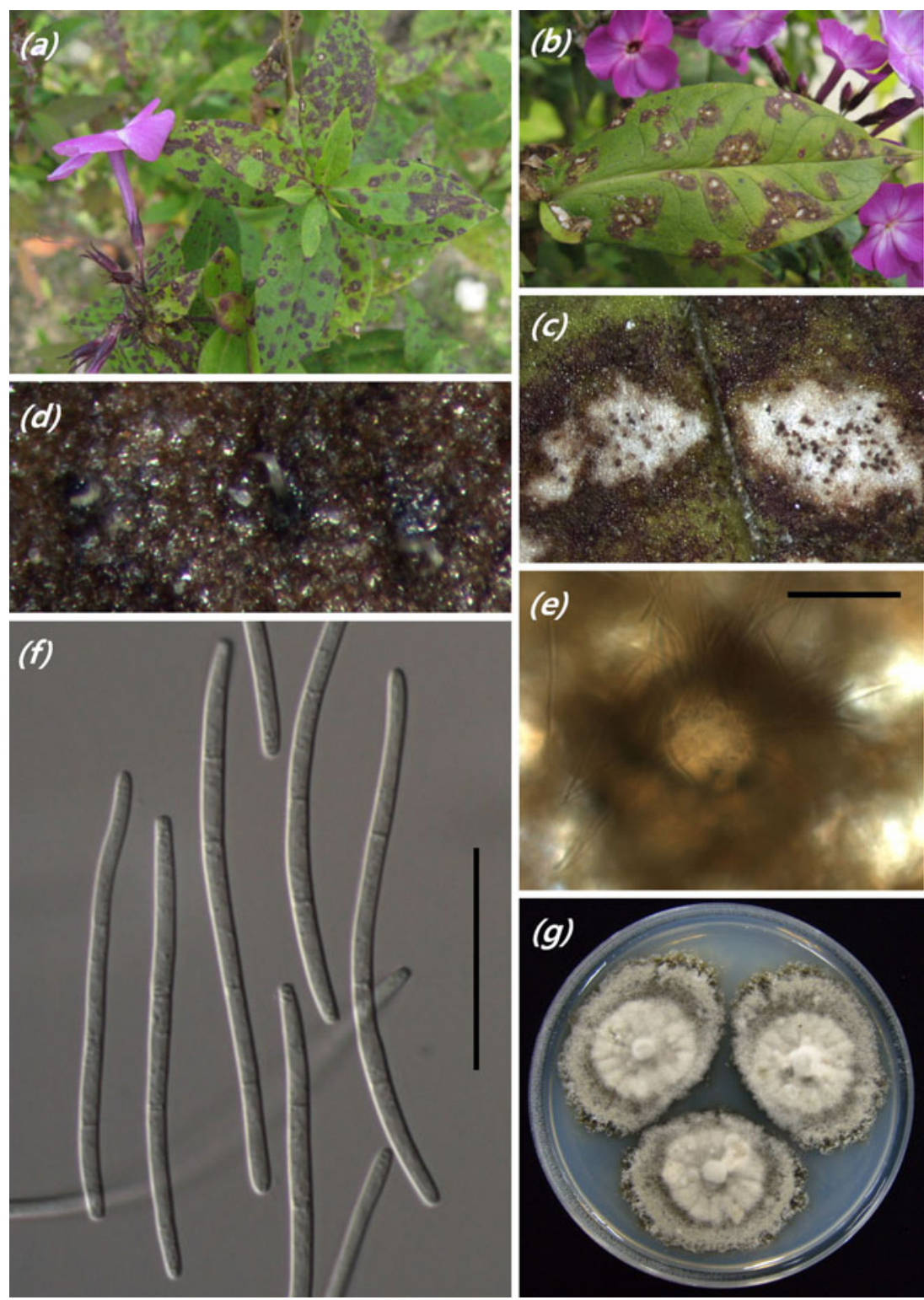

Table 1 Comparison of morphological characteristics of Septoria phlogis on Phlox spp. examined by different authors

\begin{tabular}{|c|c|c|c|c|c|}
\hline Characteristics & Saccardo (1878) & Jørstad (1965) & Bai et al. (2003) & Priest (2006) & Present isolate \\
\hline \multicolumn{6}{|l|}{ Lesions } \\
\hline center & white & light-colored & grayish white & creamy brown to white & grayish white \\
\hline margin & dark brown & dark purple or brown & brown & purple-brown & purplish brown \\
\hline \multicolumn{6}{|l|}{ Conidiomata } \\
\hline caespituli & $-*$ & epigenous & epigenous & epigenous & mostly epigenous \\
\hline diameter $(\mu \mathrm{m})$ & $150-200$ & $65-130$ & $80-130$ & $90-150$ & $60-120$ \\
\hline ostiole $(\mu \mathrm{m})$ & - & - & - & $20-30$ & $20-40$ \\
\hline \multicolumn{6}{|l|}{ Conidia } \\
\hline size $(\mu \mathrm{m})$ & $40-60 \times 1-2$ & $16-54 \times 1.5-2(-2.5)$ & $42-75 \times 2-2.5$ & $(35-) 50-73 \times(1-) 1.5-2$ & $25-75(-95) \times 1.5-2.2$ \\
\hline no. septa & $1-3$ & $1-3(-4)$ & $1-5$ & $1-4$ & $1-5$ \\
\hline Host species & P. paniculata & P. $\times$ hortorum & P. paniculata & P. drummondii, $P$. paniculata & P. paniculata \\
\hline
\end{tabular}

-*: Not described 
in the Korean Agricultural Culture Collection of the National Academy of Agricultural Science (Accession No. KACC43947). The isolate was used for molecular analysis and pathogenicity test.

Morphological identification of the fungal isolates was supported by molecular data. Fungal DNA was extracted from the mycelia of 4-week-old colonies with DNeasy Plant Mini DNA Extraction Kits (Qiagen, Valencia, CA). The internal transcribed spacer (ITS) region of rDNA was amplified using the ITS1/ITS4 primers (Crous et al. 2004) and sequenced using an ABI Prism 337 automatic DNA sequencer (Applied Biosystems, Foster City, CA). The resulting 510 bp sequence was deposited in GenBank (Accession No. JQ713863). A BLAST search showed that there was no matching sequence of S. phlogis. Therefore, this was the first ITS sequence for the species submitted to GenBank. The ITS sequence showed $>99 \%$ similarity with those of many Septoria species, indicating their close phylogenetic relationship.

Conidiomata matured after 4 weeks when PDA plates were incubated under fluorescent illumination for $12 \mathrm{~h}$ photoperiods at $25^{\circ} \mathrm{C}$, producing numerous conidia. Pathogenicity of the isolate was confirmed by inoculating the leaves of three potted plants with a conidia suspension (ca. $2 \times 10^{5}$ conidia $/ \mathrm{ml})$. Three non-inoculated plants served as controls. The plants were covered with plastic bags to maintain $100 \%$ relative humidity for $48 \mathrm{~h}$. After 10 days, typical leaf spot symptoms, identical to the ones observed in the field, started to develop on the leaves of inoculated plants. No symptoms were observed on control plants. Septoria phlogis was re-isolated from the lesions of inoculated plants, fulfilling Koch's postulates.

Leaf spot disease associated with $S$. phlogis is nearly circumglobal, including North America, Europe, Oceania, and Asia, on several species of Phlox (cf. Farr and Rossman 2012). Shin and Sameva (2004) recorded Phlox drummondii as host plant of this fungus in Korea. To our knowledge, this is the first report of Septoria leaf spot on P. paniculata in Korea. This disease seems not to be a serious threat to plant vigour, but can greatly detract from the beauty of this plant in landscape plantings.

Acknowledgements This work was supported by a grant from Regional Subgenebank Support Program of Rural Development Administration, Republic of Korea.

\section{References}

Bai JK, Lu GZ, Sun JD, Liu WC, Zhou YL, Yu L, Liang JY, Luo FX (2003) Flora Fungorum Sinicorum. Vol. 17. Sphaeropsidales, Ascochyta, Septoria. Science Press, Beijing, p 372

Crous PW, Groenewald JZ, Pongpanich K, Himaman W, Arzanlou M, Wingfield MJ (2004) Cryptic speciation and host specificity among Mycosphaerella spp. occurring on Australian Acacia species grown as exotics in the tropics. Stud Mycol 50:457-469

Farr DF, Rossman AY (2012) Fungal databases, systematic mycology \& microbiology laboratory, ARS, USDA. Retrieved Mar. 3, 2012, from http://nt.ars-grin.gov/fungaldatabases/

Jørstad I (1965) Septoria and septoroid fungi on dicotyledons in Norway. Oslo University Press. p 110

Park MJ, Park JH, Lee SG, Shin HD (2010) First confirmed report on powdery mildew of Phlox paniculata caused by Golovinomyces magnicellulatus in Korea. Plant Pathol J 26(3):295

Priest MJ (2006) Fungi of Australia: Septoria. CSIRO Publishing. p 259

Radulescu E, Negru A, Docea E (1973) Septoriozele din Romania. Bucuresti, Romania, p 325

Saccardo PA (1878) Michelia 1. p 184

Shin HD, Sameva E (2004) Septoria in Korea. National Institute of Agricultural Science and Technology, Suwon, p 183 